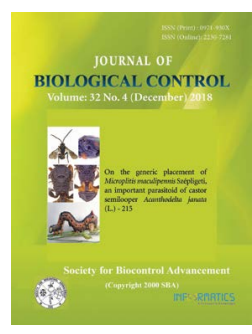

\title{
Integrated disease management approaches for control of late blight of potato and enhancing the growth of potato
}

\author{
SUMIT KUMAR*, S. K. BISWAS and H. G. PRAKESH \\ Department of Plant Pathology, C. S. Azad University of Agriculture and Tech, Kanpur-200802, Uttar Pradesh, India \\ *Corresponding author E-mail: samirkrbiswas@rediffmail.com
}

\begin{abstract}
Experiments were conducted to study integrated approach in the management of potato blight. The result showed that T1 treatment (soil application of FYM @ 125gm/pot + waste of mushroom cultivation with Trichoderma harzianum @ $5 \mathrm{gm} / \mathrm{kg}+$ tuber treatment with Azotobacter@ $9 \%$ + foliar spray with Ridomil @ 0.25\%) was the best to show minimum disease severity, representing 9.16\% as against 76.40\% in case of control at 21 days of observation. The treatment also exhibited increased tuber germination and plant height of potato showing the value 100 per cent and $44.5 \mathrm{~cm}$ at 30 days age of plant. The maximum number of large size tuber and total yield with $668.6 \mathrm{~g}$ was also recorded from treatment T1. Thus, integration of FYM + mushroom waste as soil application + bio formulation as tuber treatment + fungicides as foliar spray can be efficiently applied for management of late blight and also get enhanced yield of potato.
\end{abstract}

KEY WORDS: Bioagent, disease severity, growth parameter, late blight, organic matter, potato

(Article chronicle: Received: 07-08-2018; Revised: 10-11-2018; Accepted: 15-12-2018)

\section{INTRODUCTION}

Potato (Solanum tuberosum L.) ranks third in importance as a food crop, following wheat and rice belonging to the family Solanaceae (Hawkes, 1989). It is originated in the regions of Peru and Bolivia of Andreas high land of South America and was utilized by the Incas about 2,000 years before the arrival of Spanish explorers. Recently, potato is grown in about 150 countries of the world and total area under potato production during 2011 was about 19.33 million hectares with a total production of about 321 million tons which is consumed by over a billion people across the globe, of which half are in the developing countries.

In India, the major potato growing states are Uttar Pradesh (14430.28 MT), West Bengal (11591 MT), Bihar (6640.60 MT), Gujarat (2499 MT), and Madhya Pradesh (2299 MT). Potato is grown over 20.45 lakh hectares with an annual production of 480.86 lakh tons and having productivity of 23.07 tons per hectare (National Horticultural Research and Development Foundation Nasik, 2016). The production and productivity of potato is impressive in India However, in the background of increasing population there is a need for more production from same piece of land. Plant diseases are major constraints of potato production. Among several diseases, late blight caused by Phytophthora infestans (Mont) de Baryis is one of the major yield limiting factors in India.

The pathogen perpetuates through soil and seed tubers through production of resting spore i.e., oospore. Therefore, management of the disease can be done through host resistance, cultural adjustments, biological management and use of fungicides. Cultural practice like field sanitation; summer ploughing, soil solarization, soil amendments and crop rotation etc., can minimize the possibility of disease but cannot completely control the disease in standing crops. The use of resistant variety is another important method which is reliable and cheap for management of plant disease but due to development of new races of pathogen, the resistant variety becomes susceptible one. Hence, the use of fungicides is the last and only method for management of plant disease. But continuous use of fungicides may develop resistant strain of the pathogen which has also adverse effect to human health. Continuous use of fungicides leads to increase in the development resistance population of $P$. infestans to both systemic and even protective fungicides. Therefore, there is a need to search for new management strategy which can keep environment free from chemical hazards and pollutions. 
The only one and single method is use of Integrated Disease Management which ultimately fulfils the customer desire to protect their livelihood. Various practices like cultural, chemical, biological control and use of resistant varieties have been used alone and in combination to manage the disease as reported by several workers (Singh, 1996; Joshi and Pundhir, 2013; Shalibala and Pundhir, 2008;). Mishra et al. (2016) reported that integrated approach reduced the disease severity of early blight and increased crop yield of tomato. Morajdhwaj et al. (2016) also found that incorporation of bio-fertilizers in soil + tuber treatment with bio agents + foliar spray with bio formulation effectivity managed the late blight of potato. Therefore, keeping the above-mentioned account in the mind, present investigation was carried out to develop an efficient "Integrated Disease Management" (IDM) strategy to combat late blight of potato and also to enhance growth and yield of potato.

\section{MATERIALS AND METHODS}

The present investigation based on glasshouse experiment as well as laboratory were undertaken at Department of Plant Pathology, Chandra Shekhar Azad University of Agriculture and Technology, Kanpur during crop season 2015-17. The procedure and techniques applied during the course of investigations are elucidated below.

\section{Isolation, purification and identification of Phytophthora infestans}

\section{Collection of infected plant samples}

Late blight infected leaves were collected from Vegetable Research Farm, C. S. Azad University of Agriculture and Technology, Kalyanpur (Kanpur). Infected plants apparently showing typical blight like symptoms were collected and brought to the laboratory for initial examination. Diseased samples were pressed in between the fold of sterilized blotting paper and preserved at $4-6^{\circ} \mathrm{C}$ in refrigerator for further study. All the collected samples were examined in the laboratory for the presence of causal organism and virulence study.

\section{Isolations of pathogen}

A small piece of infected leaf from border of sporulating lesion along with some healthy green tissue was cut and dipped in mercuric chloride solution $(0.1 \%)$ for 30 seconds it was then rinsed in sterilized distilled water thrice and dried off with sterilized filter paper. The leaf pieces were then placed on tomato extract based medium kept in sterilized Petri plates. The plates were then incubated at $18 \pm 1{ }^{\circ} \mathrm{C}$. The Petri plates were observed daily to find out the presence of mycelium around the leave bits. As soon as the mycelia growth is notices around the bits, the pathogen was purified by hyphal tip culture method.

\section{Purification of Phytophthora infestans}

The white mycelial bits of $P$. infestans were removed from the margin of fungal colony and then transferred to another Petri-plate which was previously poured with sterilized tomato extract based medium. After purification, the pure culture of $P$. infestans was transferred on slant medium and incubated at $15-18^{\circ} \mathrm{C}$ in darkness till full growth. The culture was then transferred into the incubator at $10-12^{\circ} \mathrm{C}$ for further use.

\section{Identification of Phytophthora infestans}

The purified culture was then characterized on morphological and cultural behaviour as per described by Alexopolus et al. (1996).

\section{Design of treatments}

The experiment was conducted at the glasshouse complex, Department of Plant Pathology, C.S.A. University of Agriculture and Technology, Kanpur. The seed tubers of potato variety 'Kufri Pukhraj' were treated with bio formulations of Trichoderma harzianum, T. viride and Azotobacter separately and sown in $30 \mathrm{~cm}$ earthen pots, which were previously filled with a mixture of sterilized sandy loam and farm yard manure in the ratio of $2: 1$. In each pot, one seed tuber was sown and watered regularly. Three replications were maintained and three pots sown with untreated seed tubers served as control. The following treatments were maintained.

T1. = Soil application of FYM @ $125 \mathrm{~g} /$ pot + waste of mushroom cultivation with T. harzianum @ $5 \mathrm{gm} / \mathrm{kg}$ + tuber treatment with Azotobacter@5\%+foliar spray with Ridomil@0.25\%.

T2. = Soil application of FYM@125 g/pot + waste of mushroom cultivation with T. harzianum@5 g/kg + tuber treatment with T. harzianum@5\%+foliar spray with Mancozeb@0.25\%.

T3. = Soil application of FYM@125 g/pot + neemcake @125 g/pot + tuber treatment with T. viride@5\%+ foliar spray with Mancozeb@0.25\%.

T4. = Soil application of FYM@125 g/pot + mustard cake @ $125 \mathrm{~g} / \mathrm{pot}+$ tuber treatment with Azotobacter @ $5 \%+$ foliar spray with Carbendazim @0.05\%.

T5. = Soil application of FYM @ $250 \mathrm{~g} /$ pot + tuber treatment with T. viride@5\%+foliar spray with Ridomil@0.25\%.

T6. = Soil application of FYM @ 250 g/pot + tuber treatment with T. harzianum@5\%+foliar spray with Mancozeb@0.25\%.

$\mathrm{T} 7=$ Soil application of FYM @ $250 \mathrm{~g} / \mathrm{pot}+$ tuber treatment with Azotobacter@5\% + foliar spray with Ridomil@0.25\%.

T8. = Soil application of FYM@250 g/pot + foliar spray 
with Carbendazim @0.05\%.

T9. = Soil application of FYM @ $250 \mathrm{~g} /$ pot + mustard cake @ $125 \mathrm{~g} /$ pot+ foliar spray with Ridomil @ 0.25\%.

$\mathrm{T} 10 .=$ Soil application of FYM @ 250 g/pot (control).

Observations undertaken were as follows.

- Tuber germination (up to 10 days after sowing).

- Plant height (up to 30 days).

- Disease severity (45 days and 52 days).

- Yield (after harvesting).

\section{Tuber germination percentage}

Seed tuber treated with different bio formulations was responsible for early breaking of seed tuber. The observation on germination of tuber was taken at every 24 hours up to 10 days. Germination percentage was calculated by use of following formula

$$
\text { Germination } \%=\frac{\text { Number of germinated seed tubers }}{\text { Number of total seeds }} \times 100
$$

\section{Plant height}

For this purpose, three plants were selected randomly from tagged plots. The shoot height was measured (in $\mathrm{cm}$ ) from the soil surface at basal portion of flag leaf with the help of meter scale. The average of three plants height was divided by 3 for obtaining their mean to consider plant height.

\section{Disease severity}

\section{Inoculation with Phytophthora infestans}

At 45 days, plants were inoculated with spore suspension of pathogen. The concentration of sporangia was maintained at $10^{6}$ sporangia $/ \mathrm{ml}$. The homogenized, spore suspension were inoculated on the foliage of each plant. The plants were then covered with polythene bags for $48 \mathrm{hrs}$. to provide suitable moisture and humidity for growth and development of the pathogen.

\section{Measurement of disease severity}

Observations for measuring the disease severity were taken after 5 days of pathogen inoculation. The disease severity was recorded on a $0-9$ scale. Ten leaves were randomly selected from the pot for measurement of disease severity. The leaves with $1-9 \%$ infection received $1,10 \%$ infection received 2 , $11-25 \%$ infection received $3,26-40 \%$ infection received 4 , $4-60 \%$ infection received $5,61-70 \%$ infection received $6,71-$ $80 \%$ infection received $7,81-90 \%$ infection received $8,91-$ $100 \%$ infection received 9 (Malcolimson, 1976).

The disease severity of individual plants was calculated as per below formula
Disease severity PDI $=\frac{\text { Sum of numerical rating }}{\text { Total number of leaves examined } \times \text { maximum rating }} \times 100$

\section{Tuber yield}

Treatment effect on on tuber size and yield was circulated based on weight of total no of tubers per treatment and number of large $(>50 \mathrm{~g})$; medium $(25-49.5 \mathrm{~g})$ and small $(<25 \mathrm{~g})$ size tubers. The yield of crop was calculated by taking into account weight of all tubers.

\section{RESULTS AND DISCUSSION}

The present investigations based on glasshouse experiment as well as laboratory were undertaken at Department of Plant Pathology, Chandra Shekar Azad University of Agriculture and Technology Kanpur during crop season 2015-17.

The data presented in the Table 1 showed that the integrated disease management approaches has ability to increase seed tuber germination and vigour of plants. 100 per cent germination was recorded in T1 treatment (Soil application of FYM@125g/pot + waste of mushroom cultivation with T. harzianum @ $5 \mathrm{~g} / \mathrm{kg}$ + tuber treatment with Azotobacter@5\% + foliar spray with Ridomil@0.25\%) which was followed by T2 treatment (Soil application of FYM (a) $125 \mathrm{~g} / \mathrm{pot}+$ waste of mushroom cultivation with T. harzianum (a) $5 \mathrm{~g} / \mathrm{kg}+$ tuber treatment with T. harzianum @ 5\% + foliar spray with Mancozeb @ $0.25 \%$.) with $80 \%$ as against $46.15 \%$ in case of control. Mansoor et al. (2001) reported that the Azotobacter significantly increases the yield characters like tiller and tuber of potato. Kumar et al. (2001) investigated on strains of A. chroococum and their mutants performed better in all the varieties to increase germination and yield over control.

Plant height is an important parameter for maximisation of crop yield. The data presented in table 2 shows that the plant height was maximum in treatment $\mathrm{T} 1$ with the value of $44.5 \mathrm{~cm}$ at 30 day age of plant, followed by treatment $\mathrm{T} 2$ and $\mathrm{T} 3$ representing value of $43.5 \mathrm{~cm}$ and $42.5 \mathrm{~cm}$, respectively. From the table it is clear that all the treatments were able to increase the growth of plant over control. Rasool Azarmi et al. (2011) reported that the seed germination rate was affected by Trichoderma application and shoot height and shoot diameter, fresh and dry weight of shoot in tomato seedlings were increased significantly. They also found that soil amended by Trichoderma spp. had marked increase in leaf number and area of leaf. Chandanie et al. (2009) found that the combined inoculation of Arbuscular mycorrhizal fungi with Trichoderma synergistically increased dry shoot mass when compared with inoculation of Trichoderma and Arbuscular mycorrhizal fungi alone. 
The effect of integrated approaches on severity of late blight of potato revealed that there is a decline in disease severity due to various treatments (Table 3). Among the various IDM approaches, the minimum late blight severity was recorded in treatment $\mathrm{T} 1$ representing the value of $9.16 \%$, $14.75 \%$ and $16.95 \%$ at 7,14 and 21 days of observations as against $52.87 \%, 67.25 \%$ and $76.40 \%$ in case of control. The T2 treatment showing $10.11 \%, 15.24 \%$ and $18.35 \%$ disease severity at 7, 14 and 21 days of observations which is second highest among the treatment. The rest of the treatments were also superior over control but inferior to $\mathrm{T} 1$ and $\mathrm{T} 2$ treatments. The decrease in disease severity might be combined activity of soil amendment + tuber treatment + foliar spray of fungicide which stimulate synthesis of defense compounds in potato against $P$. infestans. Nguyen Khanh, et al. (2013) could suppress $P$. infestans by using different bio- agents, botanicals and fungicides to manage the early blight of tomato. Biswas et al. (2015) found that seed treatment and soil application with bio fertilizers of Azotobacter declined the disease severity of spot blotch from $73.7 \%$ to $42.6 \%$ in wheat. Mishra et al. (2015) reported that the minimum disease severity of early blight of tomato which was $8.56 \%$ was found in case of soil application of FYM + seed treatment with bio formulation of T. harzianum + foliar spray of Mancozeb. Morajdhwaj et al. (2016) found that disease severity of late blight was come down from 96.00 to 7.82 per cent due to soil application of FYM and mustard cake + tuber treatment with $T$. viride + foliar spray with $T$. viride.

Table 1.Effect of integrated disease management practices on germination of seed tuber

\begin{tabular}{|c|c|c|c|}
\hline Treatment & $\begin{array}{c}\text { Total no. of } \\
\text { tuber buds } \\
\text { before sowing }\end{array}$ & $\begin{array}{c}\text { Total no. of } \\
\text { tuber buds } \\
\text { germinated } \\
\text { after sowing }\end{array}$ & Germination\% \\
\hline T1 & 12 & 12 & 100 \\
\hline T2 & 10 & 8 & 80 \\
\hline T3 & 9 & 7 & 77.77 \\
\hline T4 & 13 & 10 & 76.92 \\
\hline T5 & 15 & 11 & 73.33 \\
\hline T6 & 8 & 6 & 75 \\
\hline T7 & 7 & 4 & 57.14 \\
\hline T8 & 9 & 5 & 55.55 \\
\hline T9 & 12 & 6 & 50 \\
\hline T10 & 13 & 7 & 46.15 \\
\hline CD (0.05) & 0.685 & 0.495 & 4.388 \\
\hline SE(d) & 0.326 & 0.236 & 2.089 \\
\hline C.V.\% & 3.697 & 3.795 & 3.698 \\
\hline
\end{tabular}

Table 2. Effect of different treatments on plant height (in $\mathrm{cm}$ ) of potato at different days after sowing

\begin{tabular}{|c|c|c|c|c|c|c|c|}
\hline \multirow{2}{*}{ Treatment } & \multicolumn{5}{|c|}{ Days after sowing an } \\
\cline { 2 - 8 } & $\mathbf{1}$ & $\mathbf{5}$ & $\mathbf{1 0}$ & $\mathbf{1 5}$ & $\mathbf{2 0}$ & $\mathbf{2 5}$ & $\mathbf{3 0}$ \\
\hline T 1 & 1.7 & 3.1 & 6.5 & 13.0 & 22.8 & 33.8 & 44.5 \\
\hline T 2 & 1.4 & 2.8 & 6.4 & 12.8 & 21.6 & 32.6 & 43.5 \\
\hline T 3 & 1.1 & 2.5 & 5.9 & 12.0 & 21.0 & 32.4 & 42.5 \\
\hline T 4 & 1.5 & 2.5 & 5.5 & 11.8 & 20.1 & 30.7 & 39.5 \\
\hline T 5 & 1.3 & 2.5 & 5.2 & 11.3 & 19.1 & 30.0 & 38.6 \\
\hline T 6 & 1.1 & 2.3 & 5.1 & 11.0 & 18.8 & 29.9 & 38.3 \\
\hline T 7 & 2.5 & 4.2 & 8.4 & 13.5 & 22.1 & 30.7 & 37.2 \\
\hline T 8 & 1.9 & 3.6 & 7.3 & 12.6 & 21.2 & 29.6 & 35.3 \\
\hline T 9 & 1.1 & 2.0 & 4.3 & 9.7 & 17.4 & 27.8 & 34.5 \\
\hline T 10 & 1.3 & 3.1 & 7.2 & 11.4 & 20.3 & 28.9 & 33.4 \\
\hline C.D. (0.05) & & 0.181 & 0.389 & 0.739 & 1.268 & 1.898 & 2.394 \\
\hline S.E. (D) & & 0.061 & 0.131 & 0.249 & 0.427 & 0.639 & 0.806 \\
\hline C.V.\% & 3.691 & 3.669 & 3.616 & 3.611 & 3.622 & 3.620 \\
\hline
\end{tabular}

The data presented in the table 4 shows that the maximum number of large tuber was found in $\mathrm{T} 2$ treatment with single tuber weight at $53.46 \mathrm{~g}$. From the table it is also clear that there is no large size potato in rest of the treatments. On the other hand, maximum number of medium size tuber has been found in $\mathrm{T} 2$ treatment, with average tuber weight of $49.0 \mathrm{~g}$. Similarly, maximum number of small size tuber was found in $\mathrm{T} 3$ treatment, with total weight of $527.7 \mathrm{~g}$ for 56 tubers or around $9.4 \mathrm{~g}$ for single tuber. Morajdhwaj et al. (2017) reported that maximum number of large size tuber and highest yield was recorded from the treatment soil application of FYM @ 150gm/pot + mustard cake @ 150gm/pot + tuber treatment with $T$. viride + foliar spray with bio formulation of T. viride. Tippannaves et al. (2005) had observed that the Azotobacter significantly increased the tillering, dry matter accumalation and growth parameter. Datnoff et al. (1995) found that Trichoderma spp. enhanced the growth of tomato yield. Singh et al. (2015) found that the yield of tomato crop was significantly increased by the combined application of seed treatment with $T$. harzianum + soil application of neem 
Integrated disease management approaches for control of late blight of potato and enhancing the growth of potato

Table 3. Effect of integrated disease management approaches on severity of late blight of potato

\begin{tabular}{|c|c|c|c|}
\hline \multirow{2}{*}{ Treatment } & \multicolumn{3}{|c|}{ Disease severity (\%) } \\
\cline { 2 - 4 } & 7 Days & 14 Days & 21 Days \\
\hline T1 & 9.16 & 14.75 & 16.95 \\
\hline T2 3 & 10.11 & 15.24 & 18.35 \\
\hline T4 & 11.11 & 16.72 & 21.46 \\
\hline T5 & 13.50 & 17.35 & 21.25 \\
\hline T6 & 14.22 & 18.50 & 22.65 \\
\hline T7 & 14.25 & 19.75 & 24.80 \\
\hline T8 & 14.55 & 20.35 & 24.86 \\
\hline T9 & 15.75 & 21.11 & 29.49 \\
\hline T10 & 52.87 & 67.25 & 76.40 \\
\hline CD (0.05) & 1.284 & 1.689 & 2.002 \\
\hline SE(d) & 0.611 & 0.804 & 0.953 \\
\hline C.V.\% & 4.453 & 4.306 & 4.193 \\
\hline
\end{tabular}

cake powder + foliar spray of carbendazim. Mansoor et al. (2001) also observed that the Azotobacter improved plant height and shoot dry weight significantly.

Yield parameters ultimately determine the treatment effect. Increase or decrease of yield determines the profit or loss of any cultivation. Yield parameters depend on number of large size tubers. In the present study the highest yield (668.6g/plant) was recorded from treatment $\mathrm{T} 1$ followed by treatment T2 (640.02g/plant) and T3 (607.38g/plant) (Table 4). Kachroo and Razdan (2006) reported that combined application of Azotobacter + Azospirillium with different levels of $\mathrm{N}$ significantly increased the grain yield of wheat. Indiresh et al. (2003) found that the response of potato cv. Kufri Jyoti to individual and combined inoculation of Azotobacter croococcum, Acetobacter diazotrophicus and Pseudomonas striata showed significant effect in increasing per cent emergence of tubers, numbers, tuber weight per plant, total tuber yield and marketable tuber yield. Higher yield was recorded in cauliflower (42.58 t/ha) and cabbage (56.16 t/ha) with bio dynamics package than recommended dose of FYM (a) 23.00 and $22.83 \mathrm{t} /$ ha, respectively (Pathak, 2003). Biswas et al. (2008) observed that seed treatment with T. harzianum and foliar spray with fungicides is one of the best strategy to manage brown spot and sheath blight of paddy and also to increase yield of crop. Biswas et al. (2015) also reported that seed treatment and soil application with bio fertilizers of Azotobacter significantly increased grain and straw yield of wheat. Singh et al. (2015) reported that seed treatment with T. harzianum + soil application of neem cake + foliar spray

Table 4. Effect of integrated disease management practices on tuber size and yield of potato

\begin{tabular}{|c|c|c|c|c|c|c|c|c|}
\hline \multirow{2}{*}{ Treatment } & \multicolumn{2}{|c|}{$\begin{array}{l}\text { Large } \\
>50 \mathrm{~g}\end{array}$} & \multicolumn{2}{|c|}{$\begin{array}{l}\text { Medium } \\
25-49 \mathrm{gm}\end{array}$} & \multicolumn{2}{|c|}{$\begin{array}{l}\text { Small } \\
<25 \mathrm{~g}\end{array}$} & \multirow{2}{*}{$\begin{array}{l}\text { Total yield } \\
\text { (g/plant/pot) }\end{array}$} & \multirow{2}{*}{$\begin{array}{l}\% \text { increase } \\
\text { over control }\end{array}$} \\
\hline & $\begin{array}{c}\text { Total No. of } \\
\text { tubers }\end{array}$ & Weight & $\begin{array}{c}\text { Total No. } \\
\text { of tubers }\end{array}$ & Weight & $\begin{array}{c}\text { Total No. } \\
\text { of tubers }\end{array}$ & Weight & & \\
\hline $\mathrm{T} 1$ & 0 & 0.00 & 07 & 203.38 & 39 & 465.22 & 668.6 & 94.90 \\
\hline $\mathrm{T} 2$ & 1 & 53.46 & 10 & 343.24 & 21 & 243.32 & 640.02 & 86.57 \\
\hline $\mathrm{T} 3$ & 0 & 0.00 & 02 & 79.68 & 56 & 527.7 & 607.38 & 77.05 \\
\hline $\mathrm{T} 4$ & 0 & 0.00 & 03 & 110.82 & 34 & 329.46 & 440.28 & 28.34 \\
\hline $\mathrm{T} 5$ & 0 & 0.00 & 02 & 66.6 & 39 & 335.46 & 402.06 & 17.20 \\
\hline T6 & 0 & 0.00 & 04 & 144.28 & 28 & 237.4 & 381.68 & 11.26 \\
\hline $\mathrm{T} 7$ & 0 & 0.00 & 02 & 56.68 & 31 & 309.88 & 366.38 & 6.80 \\
\hline $\mathrm{T} 8$ & 0 & 0.00 & 05 & 152.3 & 34 & 209.38 & 361.68 & 5.43 \\
\hline T9 & 0 & 0.00 & 02 & 86.26 & 24 & 257.88 & 344.14 & 0.32 \\
\hline $\mathrm{T} 10$ & 0 & 0.00 & 05 & 138.54 & 20 & 204.5 & 343.04 & \\
\hline $\mathrm{CD}(0.05)$ & 0.020 & 1.045 & 0.303 & 9.897 & 2.111 & 20.320 & 29.189 & \\
\hline $\mathrm{SE}(\mathrm{d})$ & 0.009 & 0.498 & 0.144 & 4.711 & 1.005 & 9.673 & 13.895 & \\
\hline C.V.\% & 11.401 & 11.401 & 4.205 & 4.176 & 3.775 & 3.797 & 3.736 & \\
\hline
\end{tabular}


with carbendazim significantly increased crop yield and decreased disease incidence of Fusarium wilt in tomato.

Hence, the present study has clearly shown that IDM with soil application of FYM @ $125 \mathrm{~g} / \mathrm{pot}+$ waste of mushroom cultivation with T. harzianum @ $5 \mathrm{gm} / \mathrm{kg}+$ tuber treatment with Azotobacter@ 5\% + foliar spray with Ridomil (a) $0.25 \%$ can be readily adopted to combat late blight and also to get better yield of potato.

\section{REFERENCES}

Alexopolous CJ, Mims CW, Blackwell M. 1996. Introductory Mycology. New York: John Wiley and Sons, Inc.. 717-723 pp.

Biswas SK, Ratan V, Srivastava SSL. 2008. Influences of seed treatment with biocides and foliar spray of fungicides for management of brown leaf spot (Drechslera oryzae) and sheath blight (Rhizoctonia solani) of paddy. Indian Phytopath. 61(1): 55-59.

Biswas SK, Shankar U, Kumar S, Kumar A, Kumar V, Lal K. 2015. Impact of bio fertilizers for the management of spot blotch disease and growth and yield contributing parameters of wheat. $J$ Pure Appl Microbiol. 9(4): 3025- 3030.

Chadanie WA, Kubota M, Hyakumachi M. 2009. Interaction between the arbuscular mycorrhizal fungus, Glomus mosseae and plant growth promoting fungi and their significance for enhancing plant growth and suppressing damping-off of cucumber (Cucumis sativus L.). Appl Soil Ecol. 41: 336-341. https://doi.org/10.1016/j.apsoil.2008.12.006

Datnoff LF, Parnezny K. 1995. Biological control of Fusarium crown and root rot of tomato in Florida using Trichoderma harzianum and Glomus intrarasices. Biol Control. 5: 27- 231.

de. Bary A. 1876. Research into the nature of the potato fungus Phytophthora infestans. J Royal Agr Soc England. 12: 239-269

Hawkes JG. 1989. The potato- evolution, bioderversity and genetic resources. Belhaven Press, London, UK.

Indiresh KM, Sreeramulu KR, Patil SV, Venkatesh. 2003. Response of potato to biofertilizers at graded levels of chemicals fertilizers. $J$ Indian Potato Assoc. 30(1-2): 79-80.

Joshi V, Pundhir VS. 2013. Manipulation of planting time: on option for management of late blight of potato. Pantnagar J Res. 11(2): 2481253
Kachroo D, Rzdan R. 2006. Growth nutrient uptake and yield of wheat (Triticum aestivum) as influenced by biofertolizer and nitrogen. Ind J Agronomy. 15(1): 37-39.

Kumar S, Tamara K, Jakobsen IB, Nei M. 2001. MEGA2: molecular evolutionary genetics analysis software. Bioinformatics 17(12):1244-5.

Malcomson JF. 1985. Phytophthora infestans A2 compatibility type recorded in Great Britain. Trans Br Mycol Soc. 83: 531. https://doi.org/10.1016/S0007-1536(85)80054-1

Mansoor S, Amin I, Hussain M, Zafar Y, Bull S, Briddon RW, Markham PG. 2001. Association of a disease complex involving a begomo virus, DNA 1 and a distinct DNA beta with leaf curl disease of okra in Pakistan. Plant Dis. 85: 922.

Singh Muraj, Biswas SK, Lal K, Nagar D, Singh J, Naresh P. 2016. Development of suitable package using biofertilizers for management of late blight of potato under climate change. J Pure Appl Microbiol. 10(1): 55-65.

Ngoc NK, Narendrappa T, Malvika C. 2013. Management of tomato early blight disease [Alternaria solani (Elis and Martin) Jones and Grout] through biological and chemical methods. Mysore J Agric Sci. 47(2): 241-254.

Mishra Y, Biswas SK, Lal K, Naresh P, Sushree A, Kumar N. 2016. Sustainable integrated approach for management of early blight and their effect on crop growth parameters in tomato. Bioscan 11(1): 133-139.

Rasool A, Behzad H, Abolfazl G. 2011. Effect of Trichoderma isolates on tomato seedling growth response and nutrient uptake. African J Biotechnol. 10(31): 112.

Singh R, Biswas SK, Nagar D, Singh J, Singh, M, Mishra YK. 2015. Sustainable integrated approach for management of Fusarium wilt of tamato caused by Fusarium oxysporium f. sp. lycopersici (Sacc.) Snyder and Hansen. Sustainable Agric Res. 4(1): 138-147.

Shaibala M, Pundhir VS. 2008. Efficacy of fungicides and bio - agents against late blight severity, infection rate and tuber field of potato. J Plant Dis Sci. 3(1): 4-8.

Singh D. 1996. Fungicidal spray schedule for economic management of potato late blight in North-Western hills of India. Indian J Mycol Pl Pathol. 26(3): 252-255.

Tippannavar CM, Kutkaeni JB, Reddy R. 2005. Toxicity of wheat seed diffusates on the growth of seed borne Azotobacter isolate. Crop Res Hisar 25(2): 337-340. 